\title{
A comparative study on undergraduate marketing curriculums in Chinese and British Universities
}

\author{
Tian Yuan \\ school of economics and management, xi 'an university, Xi'an, Shannxi, China \\ 846983993 @qq.com
}

\begin{abstract}
Keywords: Chinese and British universities marketing undergraduate, Marketing Major, Curriculum
\end{abstract}
\begin{abstract}
China, and analyzes the characteristics of British marketing undergraduate curriculum, such as flexible curriculum, emphasis on the cultivation of students' critical thinking, and more links of practical education. This paper compares the characteristics of the marketing major in Chinese universities, such as the emphasis on the teaching of basic professional curriculums, the weak link of practical education and the weak critical thinking ability of students, and puts forward some Suggestions for the marketing major in Chinese universities.
\end{abstract}

\section{Introduction}

With the rapid development of China's economy, the job market has become more and more demanding for marketing professionals. In China, marketing undergraduate education is the foundation and important link for universities to train marketing talents. The undergraduate major of marketing is not only the foundation of postgraduate education, but also an important way to directly supply talents to industrial and commercial enterprises. ${ }^{[1]}$ The cultivation of undergraduate students is different from that of master's and doctoral students, and its requirements for curriculum setting are more specific and detailed than those of graduate students.

In 2019, the ministry of education released 2018 statistics on Chinese students studying abroad. The total number of Chinese students studying abroad in 2018 was 662,100, it said. Of these, 30,200 were government-funded, 35,600 were government-funded, and 596,300 were self-funded. In 2018, a total of 519,400 students of various types returned home. Of these, 25,300 were publicly funded by the state, 26,500 by their employers, and 467,600 studied abroad at their own expense. The number of students studying abroad increased by 53,700 , or $8.83 \%$, in 2018 compared with 2017 . The number of students returning from overseas study increased by 38,500 , or $8.00 \%$. Therefore, foreign business education is attractive to Chinese students. The report 2019 on studying abroad in the UK (the report) was released. According to the report, business students accounted for $56.09 \%$ of UK higher education applicants in 2017-2018, with Chinese students still focused on business. Communications and literature and education came second and third in the list of students applying to study in the UK, accounting for 9.29 per cent and 6.99 per cent of the total. The research on undergraduate marketing education curriculum in China and Britain has certain practical significance, and it is necessary to conduct in-depth discussion, so as to dig out the problems in the curriculum of undergraduate marketing education in China.

\section{Comparison of undergraduate marketing curriculum in Chinese and British universities}

\subsection{Implementation of undergraduate marketing curriculum in British universities}

The undergraduate major of marketing in British universities has a long history, and the teaching level and academic level are among the top in the world. The ranking of the top business schools in the world is not a simple decoration. It comes from the efforts of the top schools in the UK. ${ }^{[2]}$ The teaching force, education quality and academic level of the top business schools in the UK are all recognized by the world's education sector, and they continue to develop healthily. Most of the teachers of business curriculums in British universities are elites from the world's business front. This 
unique advantage not only enriches students' learning materials, enhances the interest of curriculums, but also provides good conditions for students' employment. The marketing curriculums of British universities pay special attention to the cultivation of students' innovative thinking ability. ${ }^{[3]}$ The undergraduate curriculum of marketing major cultivates students' thinking ability through two aspects. On the one hand, critical thinking activities are added to students' curriculums; on the other hand, curriculums related to management decision-making are provided. The main basic curriculums of marketing undergraduate major in British universities include Economic Analysis for Business Decisions, Data, Models, and Decisions, Communication for Managers, Organizational Processes, Financial Accounting, Team Project. ${ }^{[4]}$ The main elective curriculums include: Global Marketing, Consumer Behavior, Advertising \& Integrated Communications, New Product Development Marketing Research, Pricing Strategies, Managing Brands, Identity \& Experiences, High Technology Marketing \& Entrepreneurship. Generally speaking, the undergraduate curriculum of marketing in British universities is more flexible than that in Chinese universities, and pays more attention to the development of students' critical thinking and practical ability.

\subsection{Implementation of undergraduate marketing curriculum in Chinese universities}

China's marketing undergraduate majors in order to adapt to the needs of market economy and social development, pay attention to cultivating students' moral, intellectual, physical, all-round development, makes the student to have the solid basic theory of economics, management, and master the basic theory and method of marketing, have good awareness of innovation, entrepreneurship and practical skills, able to skillfully use of modern means such as a foreign language and computer in enterprises and institutions engaged in marketing management, marketing planning, sales management, e-commerce, have innovation spirit, skill, high quality applied talents. Curriculums require students to have the ability to solve complex problems, the ability to market marketing professional field complex problems in comprehensive analysis and research, and through the literature research, market survey, questionnaire design, data analysis and other methods, especially for all kinds of enterprise electronic commerce enterprise comprehensive analysis and research, the practical problems put forward for reasonable and effective conclusion, and put forward the corresponding countermeasure suggestion or solution ${ }^{[2]}$. In terms of entrepreneurial innovation, focus on cultivating the students master the basic knowledge required to conduct business activities, with integration of entrepreneurship resources, design business plan and establish and management of enterprise's comprehensive quality, innovative consciousness and innovative ability, host or take an active part in school or college students' innovative undertaking projects at the provincial level and participate in all kinds of innovative entrepreneurial activity. The major of marketing in Chinese universities is management. ${ }^{[5]}$ Core curriculums include microeconomics, macroeconomics, principles of management, marketing, consumer behavior, market research and prediction, modern advertising, introduction to e-commerce, business communication and negotiation. Upon graduation, students are required to complete a total of 163 credits, including 39 credits of compulsory public basic curriculums, 8 credits of public elective curriculums, 20 credits of compulsory basic curriculums, 23 credits of compulsory core curriculums, 31 credits of elective curriculums (major), and 41 credits of concentrated practice curriculums. The second-class practice and innovation and entrepreneurship activities are about 8 credits, not included in the total credits.

\section{Some suggests on the undergraduate curriculums of marketing in China}

Based on the above comparative analysis, this paper has the following Suggestions for the undergraduate marketing curriculum in China:

First of all, the curriculum setting of marketing specialty should strengthen the teaching link of practice and design the corresponding teaching link as the main line of each work link of the marketing post in the industry. The combination of classroom teaching, project simulation, entrepreneurship competition, dual-practice training base and dual-tutorial system enables students to change from theoretical knowledge to direct experience, from professional knowledge to professional skills, and from individual skills to professional ability. ${ }^{[6]}$ At the same time, according 
to the requirements of the market marketing professional characteristics, improve and enrich the teaching method, the integrated use of training innovation case teaching role playing, talk show, video teaching and extracurricular training and various teaching methods, training, implement classroom interaction research training after class, self cultivation series at ordinary times, thus improve the improve marketing professional students' practical ability and comprehensive quality.

Second, establish a dual mentor system. Double tutorial system refers to the implementation of "double tutorial system" in which a student is equipped with on-campus academic tutors and offcampus practical tutors in the four years of college. Generally, there are no more than 10 students under the guidance of the academic tutor in each school. In principle, the tutor shall instruct the students once a week, mainly individually, and the time and method shall be negotiated and agreed by the tutor and the student. ${ }^{[3]}$ The guidance of external practice mentors is usually provided by senior managers of local reputable enterprises in xi 'an. There are usually no more than 10 students, and the time and methods are agreed by the mentors and students. There is also a correspondence between on-campus mentors and off-campus mentors, that is, an on-campus mentor and one or more offcampus mentors' mentor the same group of students.

Thirdly, innovate case teaching method. Case teaching is the result of the $1920 \mathrm{~s}$, by the Harvard Business School (Harvard Business School) advocated, at that time is to adopt a very unique case type teaching, these cases are from the real situation or event of Business management, through this way, help to cultivate and develop the students actively participate in class discussion, after implementation, considerable performance. And we here of the case teaching method of "innovation" is a recent business management to local enterprises in case of the real scenes and events of a kind of teaching method (case - -based would), in this case the teacher plays the designer and the role of incentives, encourage students to actively participate in the discussion, not like the traditional teaching method, teacher is a man of great learning, play and imparting knowledge, and students playing the roles of the participants and imitators, so that the students can do it illustrates its real, better combined with real business activities. ${ }^{[7]}$

Finally, double training base system. Dual training base system means that students carry out a series of practical teaching activities through the two platforms of on-campus training base and offcampus training base in addition to classroom contents, so as to better integrate theory with practice. Double training base was built on schools and businesses in the voluntary, on the basis of market development projects of cooperation, the school mainly provide intelligence and human resources, the enterprise mainly provide investment and management of the project, both of us to achieve the established target market together, with the signing of the agreement form to determine their respective rights and obligations. The dual training base system also provides the best way to improve the "dual teacher" quality of marketing teachers.

\section{References}

[1] Wu Xingbai. Case collection in case teaching [J].Teaching and management, 2007(8): $61-63$.

[2] Colorado Department of Education (CDoE). (2016b). District Dashboard. Retrieved from http://www2.cde.state.co.us/schoolview/dish/dashboard.asp.

[3] Culatta, R. (2015). Constructivist theory (Jerome Bruner). Retrieved from $\mathrm{http}: / / \mathrm{www}$.instructionaldesign.org/theories/constructivist.html.

[4] Dabbagh, N., \& Kitsantas, A. (2012). Personal learning environments, social media, and selfregulated learning: A natural formula for connecting formal and informal learning. The Internet and Higher Education, 15(1), 3-8.

[5] DeGuzman, P. (2008). Effects of help-seeking in blended high school biology class. (Doctoral dissertation, University of Southern California).

[6] Farmer, J. (1999). The history of higher education: Pre-1636. Retrieved from http://cep.jmu.edu/ahrd670/student\%20papers/jacque.html. 
[7] Feldon, D., \& Kafai, Y. (2008). Mixed methods for mixed reality: Understanding users' avatar activities in virtual worlds. Educational Technology Research \& Development, 56(5/6), 575-593. doi:10.1007/s11423-007-9081-2. 